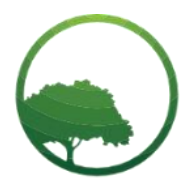

Research in Business \& Social Science

IJRBS VOL 10 NO 4 ISSN: 2147-4478

\title{
Demographic factors and turnover intentions of teachers' in public secondary schools in Kenya
}

\author{
(D) Onesmus Kamau ${ }^{(a) *}$ (iD) Stephen Muathe ${ }^{(b)}$ (iD) Lawrence Wainaina ${ }^{(c)}$ \\ ${ }^{(a, b, c)}$ School of Business, Kenyatta University, Nairobi, Kenya
}

\author{
A R T ICLE INFO \\ Article history: \\ Received 12 December 2020 \\ Received in rev. form 25 March 2021 \\ Accepted 17 May 2021 \\ Keywords: \\ Demographic factors, teachers, \\ turnover intentions, public secondary \\ schools, cross tabulation, Kenya \\ JEL Classification: \\ I2, JO, N3, O15
}

\begin{abstract}
A B S T R A C T
This study aims to investigate the effect of demographic factors on the turnover intentions of teachers in public secondary schools in Murang'a county Kenya. The study was guided by the following specific objectives: To investigate the association between age and education and turnover intentions; to establish the association between gender and turnover intentions; to determine the association between tenure and turnover intentions and to establish the association between educational level and turnover intentions. The study was guided by the Social exchange and Organization equilibrium theories. This study was a cross-sectional study and adopted descriptive and explanatory research designs. The target population was 3752 Teachers Service Commission (TSC) teachers in 304 public secondary schools in Murang'a county Kenya. The study thus used multi-stage random to select a sample size of 400 teachers and 40 schools. A self-administered questionnaire was used to collect the demographic data. Data were analyzed using cross-tabulation and Pearson Chi-square statistics. The study findings indicated that age has a significant association with turnover intentions while employee tenure, gender, and educational level have no significant association with turnover intentions.
\end{abstract}

(C) 2021 by the authors. Licensee SSBFNET, Istanbul, Turkey. This article is an open access article distributed under the terms and conditions of the Creative Commons Attribution (CC BY) license (http://creativecommons.org/licenses/by/4.0/).

\section{Introduction}

Teachers' shortages are frequently viewed to negatively affecting the quality of education and therefore understanding the reasons behind the shortages is absolutely crucial to education planners and policy makers (Wamukuru, 2016). One cause of this shortage is turnover of employees. Therefore, turnover of employees is of great concern to Human resource (HR) managers because it affects organizations' operations. The turnover among employees can be either voluntary or involuntary. Voluntary turnover occurs when employees leave their current employment on their own volition while involuntary turnover occurs when the organization chooses to discontinue the services offered by the employees.

Turnover intentions as opposed to real turnover has continued to be used in studies to predict turnover in organization because of the ease to measure turnover intentions as opposed to real turnover which may be difficult due to lack of data on employees of who have actually left (Verhees, 2012) and also because of its ability to predict actual turnover (Bhat, 2014). Park and Kim (2009) asserts in the decision-making process of the employee's turnover intentions constitute the final cognitive step whereby an employee actively opts to quit and starts looking for employment elsewhere. They further stated that employee intentions to quit the current job starts with mere thoughts and then statements by the employee that he/she desires leave the employer. Just like actual turnover intention (intention to leave) has negative effects. Chughtai (2013) asserts that when employees have thoughts of quitting it affects their loyalty to the organization and it may finally lead to the actual quitting of the valuable employee. Also according to Tarmizi (2008) intention to leave also affects other employees as it reduces their commitment within the organization. Krishman and Sigh (2010) assert that teachers' turnover intention (intention to leave) leads to reduced motivation hence hindering achievement of school's goals. It is therefore important to enhance teachers' retention by reducing intention to leave so as to improve teaching and learning processes in schools (Kamau, Muathe \& Wainaina, 2020a).

* Corresponding author. ORCID ID: 0000-0001-8408-6718

(C) 2021 by the authors. Hosting by SSBFNET. Peer review under responsibility of Center for Strategic Studies in Business and Finance.

https://doi.org/10.20525/ijrbs.v10i4.984 
Factors contributing to turnover intentions have been group into four; demographic factors, personal factors, pull and push factors (Nhema \& Mutenheri, 2016). This study focused on the demographic factors which according to Likoko, Ndiku and Mutsotso (2017) there is limited research when it comes to the association between demographic factors and turnover intentions. Review of literature has also not identified a study linking demographic factors to turnover intentions among teachers in public secondary schools in Kenya.

According to Hayes (2015) literature indicate demographic factors such age, gender, education level and tenure contribute to turnover and turnover intentions. Couch (2011) posit that employees who are older are not likely to leave compared to younger employees. Banken (2010) asserts that education level might affect turnover intentions because mostly the highly educated employees may be more ambitious and may have more different options in different organizations so may have more intentions to leave. The author further notes that, tenure might affect turnover intentions because long tenured employees have built a career and may desire to stay because they have acquired more in the organization. Studies have also indicated that between male and female, women tend to have high intention to leave than men (Begüm, Orhan \& Haluk, 2015).

The government of Kenya through Teachers Service Commission (TSC) in its endeavors to make teaching attractive and also to ensure teachers retention has developed various policies. Manthi, Kilika \& Kimencu (2018) posit that the TSC has also taken some of the Human Resource (HR) functions to the counties thus bringing them closer to teachers. Despite the Government intervention through various policies the problem of teacher turnover intention still persists (Kamau, Muathe \& Wainaina, 2020 b). Study by Chepkemboi, Kiriago and Iravo (2013) found that majority of teachers indicated that given an alternative employment they would leave TSC. Another study by Njung'e (2015) among teachers in Gatanga Sub County of Murang'a County found that $65.7 \%$ of teachers indicated that they were thinking of leaving the profession. Nationally it has been reported that 129,600 out of the 288,000 teachers had intention to leave the teaching profession in 2015 (Oduor, 2015). Recent study by Ekabu (2019) revealed 64.2\% of the respondents intended to leave teaching in secondary schools in Meru County, Kenya. These statistics thus indicate a high rate of intention to leave among teachers in Kenya. It is thus necessary to identify factors contributing to intention to leave among teachers in public secondary schools.

Though there are studies linking demographic factors to turnover intentions, majority of these studies have been carried out in other countries and those carried in Kenya did not focus on public secondary schools. Mutune and Orodho (2014) indicated that the teachers union has reported that besides inadequate number of teachers in secondary schools there is also high teacher turnover rate in the country. Thus, understanding the relationship between demographic variables and turnover intentions is necessary since it will help the teachers' employer and other policy makers develop policies that will enhance employee retention. Thus this study sought to establish the association between demographic factors and turnover intentions of teachers in public secondary schools in Murang'a County, Kenya. The study therefore was out to answer the following questions:

i. Is there significant association between gender and turnover intentions among public secondary schools' teachers in Murang'a County, Kenya?

ii. Is there significant association between age and turnover intentions among public secondary schools' teachers in Murang'a County, Kenya?

iii. Is there significant association between tenure and turnover intentions among public secondary schools' teachers in Murang'a County, Kenya?

iv. Is there significant association between education level and turnover intentions among public secondary schools' teachers in Murang'a County, Kenya?

The next part of this paper is organized as follows. The second section focuses on a review of literature related to the study which highlights the theories and empirical studies. The third section discusses the methodology while the fourth section presents the results and discussion. Finally, conclusions and implications of the study are presented in the final section

\section{Literature Review}

\section{Theoretical Review}

The theories underpinning this study are the Social Exchange Theory (SET) and Organization Equilibrium Theory (OET). SET is built on the principle that in organizations relationships advance with time through trust, loyalty and mutual commitments so long as the rules of exchange are respected (Crospranzano \& Mitchell, 2005). By abiding to these rules each party feels obligated to each other. SET suggests that in situation where individuals feel that in their social relationships there is reciprocity such individuals are likely to be comfortable with and continue in such relationships. From the SET perspective employees tend to examine the quality of their relationship with their organization and when they find presence of quality relationship, they get motivated. Social relationship are based on sense of reciprocity between the parties involved such that individuals have expectations from the organization which may include fair and adequate rewards, career opportunities, job security, and emotional support (Eisenberger, Huntington, Hutchinson \& Sowa, 1986). According to Wittmer, Martin and Tekleab (2010) this theory explains the relationship between employers and employees in the turnover intentions decisions since there is expectation of reciprocity between employees and their employers. This therefore imply that when the employees' trust that the employer appreciates their inputs to the organizational goals and is concerned about their well-being, employees will give their whole and intention to leave will reduce 
(Rhoades \& Eisenberger, 2002; Ng \& Sorensen, 2008). Individuals will therefore not think about leaving their current employer if they feel the employer is reciprocating to their inputs irrespective of their age, tenure education levels and position in the organization. Organization Equilibrium Theory (OET) was propagated by March and Simon in 1958. The theory stresses the need to balance between employees' and organization's contributions and inducements. The equilibrium theory postulates that when an institution rewards an employee more than the employee's contribution to the institution, the individual will not think about leaving the institution (March \& Simon, 1958). That is there has to be a state of balance or equilibrium between the organization's inducement and the employee's input. In relation to these study variables, if organizations do not provide better terms for young people who are joining their firms the likelihood of them leaving would be high once they obtain experience since one will feel their contribution is more than organization inducements. If the worker finds no recognition after increasing his or her education level or long tenure thoughts of leaving may arise.

The theory further posits that factors that influence an employee's loyalty are perceived desirability and perceived ease of leaving the organizations. Perceived desirability relates to job satisfaction while perceived ease of leaving the organization relates with perceived alternatives in the market (Mensah, 2014). That is when an individual is comfortable in the current employment he/she will not think about leaving however, if other employment alternatives are available an individual's probability of leaving increases. Organization should thus endeavor to offer competitive terms to its employees in order to increase intention to stay. These theories thus help to explain the relationship between demographic factors and turnover intentions.

\section{Turnover Intentions}

Bhat (2014) suggests three reasons why turnover intention instead of actual turnover has been the focus of most researchers. First according to Steel \& Ovalle (1984) an individual own opinion on intent to leave best predicts employee turnover. Secondly, attitude behavior theory supports this assertion (Fishbein \& Ajzen, 1975) and thirdly, there is empirical evidence showing significant association between employee's turnover intent and actual turnover (Cotton \& Tuttle, 1986). Perez (2008) posits that although measurements of actual turnover and turnover intention have been done separately, it is expected that as the intention increases actual turnover would increase. Park and Kim (2009) assert that employee turnover intention is usually the last move before the employee decides to quit his or her job. Thus turnover intention is usually considered as the last signal given by an employee prior to quitting a job. Ngo-Henha (2017) notes that, the terms intention to quit or leave, turnover intent and turnover intentions have been used by authors synonymously to show the likelihood that an employee will leave the current employment. This explains why most studies on turnover intentions have measured turnover intention in terms of intention to leave. This study measured turnover intentions in terms of intention to leave and intention to stay.

\section{Age and Turnover Intentions}

According to Cotton and Tuttle (1986) when people get older they become used to their work and also grow relations within the firm and therefore their likelihood of leaving is very low. This assertion is supported by Martin and Roodt (2008) and Couch (2011) who note that old people tend to have high intention to stay since they have invested more in the firm. A study by Hayes (2015) in Texas with a sample size of 187 found a negative significant relationship between age and turnover intentions. The study concluded that as a worker age increases intention to leave reduces. The study respondents were drawn from different industries however the study used non-probability sampling method and so the study could only be generalized to the population of origin (Bornstein, Jager \& Putnick, 2013). Begüm et al. (2015) did a study where a total of 297 out of 400 participants responded to the questionnaires. This study which took place in the hotel industry in Turkey found that age was a significant determinant of turnover intentions whereby older people had a lower intention to leave compared to young people. This study context was in a hospitality industry while the current study took place in and education sector. Similar results had also been reported by Monk (2012) study which established that older workers are more likely to stay in their current employment than younger employees.

\section{Gender and Turnover Intentions}

Zulfqar, Sharif, Saeed and Niazi (2011) assert that men are more satisfied whenever they achieve more on the job whereas women tend to value both work and family which points to the fact that the male employees are likely to put their job first hence unlikely to quit due to family matters. A study by Begüm et al. (2015) found a significant relationship between gender and turnover intention whereby women were found to have a higher intention to leave than men. However, other studies found contrary results which include study by Hayes (2015) and Likoko et al. (2017) who found no significant relationship between gender and turnover intentions. Bal, De Cooman and Mol (2013) assert that employees who have been with an organization for long can have low intention to leave when fulfillment of psychological contract occurs. That is when employees' expectations are met by the employer like improved pay and promotions employees may not think of leaving. Butler, Brennan-Ing, Wardamasky and Ashley (2014) on the other hand note that employees who have stayed for a short period of time tend so start thinking about quitting when they find the management breaks their promises since they feel not valued.

\section{Tenure and Turnover Intentions}

According to Maden (2014) employees who have stayed for long time in an organization are usually reluctant to leave because the long period has enabled them to acquire organization investment. This investment could be in form of experience and skills acquired and relations developed over time. A study by Begüm et al. (2015) found a significant relationship between tenure and turnover 
intention whereby short tenured employees had a high intention to leave than long tenured employees. Another study by Likoko $e t$ al. (2017) among academic staff in a diploma teachers' college in Kenya established tenure having a significant effect on turnover intention. The study concluded that probability of employee leaving decreases with increase in tenure. However a study by Hayes (2015) found a non-significant negative weak correlation between length of tenure and turnover intentions.

\section{Education and Turnover Intentions}

Brown, Hyatt and Benson (2010) posit that as a result of attaining higher academic qualification, employees agitate for better remunerations and other benefits which might not be provided by the current employer and therefore they tend to exhibit a high intention to leave. On the same note Stanley, Vandenbergher, Vandenberg and Bentein (2013) state that when employee attain higher qualifications, they tend to improve their chances of getter better jobs so this increases their levels of intention to leave. Higher qualifications can be realized either through individual funding or sponsorship from the organization. Wright, Coff and Moliterno (2014) propose that where the organization funds or support this advancement, it should put in place barriers to exit to such employees to reduce intention to leave. Study by Ajayi and Olatunyi (2017) among teachers in Nigeria established insignificant association between academic qualifications and turnover intentions. However, study by Likoko et al. (2017) study among academic staff in diploma teachers college in Kenya found a significant and positive association between higher qualification and turnover intention. An earlier study by Agyeman and Ponniah (2014) in the micro small and medium enterprises in India had also established a significant and positive relationship between qualification and retention where it was concluded that increase in academic qualification increased intention to stay.

From the review of literature, it is evident that the association between demographic factors and turnover intentions vary from within the same sector and also in different context. Therefore, the findings of a particular study on demographic factors and turnover intentions could only be generalized in that particular context. Therefore, there was need to test this relationship in a different context to see how these variables will relate. On the basis of the literature review the study developed the following hypotheses:

i. There is no significant association between gender and turnover intentions among public secondary schools' teachers in Murang'a County Kenya.

ii. There is no significant association between age and turnover intentions among public secondary schools' teachers in Murang'a County Kenya.

iii. There is no significant association between tenure and turnover intentions among public secondary schools' teachers in Murang'a County Kenya.

iv. There is no significant association between education level and turnover intentions among public secondary schools' teachers in Murang'a County Kenya.

\section{Research and Methodology}

The research designs applied were descriptive and explanatory designs. The use of descriptive design in this study facilitated vivid description of the characteristics of the participants and nature of their responses to the research questions (Kothari, 2004). Explanatory design helped to explain how the predictor and the response variables relate (Firebaugh, 2008). The study collected data on demographic characteristics of the respondents and their turnover intentions using self-administered questionnaires from teachers in the selected public secondary schools in Murang'a County, Kenya, who were the respondents in the study. In this study, the both the independent variables and dependent variables were categorical variables. The cross tabulation and Pearson chi-square were therefore used to analyses the data. Though cross tabulation is mostly used in commercial market research, this study attempted to apply it in a different context since the variables for this study are suitable for this analysis. The use of cross tabulation usually makes it easier to understand complex scenarios than when using multivariate analysis and also help avoid the challenge of sparse cells, which could be a challenge when using discrete multivariate analysis (Feick, 1984). The cross tabulation was used to determine whether there is an association between the variables while Pearson chi square aided in testing the hypotheses. The independent variable was the demographic factors which were indicated by age, gender, tenure and education while the dependent variable was turnover intentions. The study targeted 3752 teachers from 304 public secondary schools from 8 sub-counties in Murang'a County, Kenya. The study thus used a two multi stage random sampling method to select the schools and teachers. First out of the 304 public secondary schools, 40 schools were selected from the 8 sub counties using proportionate area random sampling method. According to Gay, Mills and Airasian (2006) for small population $(\mathrm{N}<1000)$, at least $10 \%$ of the target population would be a good sample size. Mugenda and Mugenda (2003) also assert that $10 \%$ sample size is sufficient. This could have resulted to a sample size of 30 schools. However, in order to have more schools involved 40 schools were chosen which represented $13.2 \%$. This was done in order to minimize occurrence of type 1 and type 2 errors and also to increase the degree of confidence in generalizing the findings (Field, 2009). Secondly to get the teachers (participants) for the study from the chosen schools from each Sub county, the participants were randomly selected. In this study the teachers were both the unit of analysis and observation. The researchers used the Yamane (1967) formula to obtain a representative sample size of teachers from the county.

$$
\mathbf{n}=\mathbf{N} \div \mathbf{1}+\mathbf{N}\left(\mathbf{e}^{2}\right) \quad(3752) \div 1+3752\left(0.05^{2}\right)=400 \text {. }
$$

Where $n=$ number of teachers sampled, $N=$ total number of teachers, e=level of precision; Source: Yamane (1967). 
The distribution of sample size used in the study is presented in table 1.

Table 1: Distribution of Sample Size

\begin{tabular}{lllllllll}
\hline Sub County & $\begin{array}{l}\text { Number } \\
\text { of } \\
\text { schools }\end{array}$ & $\begin{array}{l}\text { Multipli } \\
\text { er effect } \\
\mathbf{1 3 . 2}\end{array}$ & $\begin{array}{l}\text { Sample } \\
\text { size for } \\
\text { schools }\end{array}$ & $\begin{array}{l}\text { Percent } \\
\text { age } \%\end{array}$ & $\begin{array}{l}\text { Number } \\
\text { of } \\
\text { teachers }\end{array}$ & $\begin{array}{l}\text { Multiplier } \\
\text { effect } \\
\mathbf{1 0 . 7 \%}\end{array}$ & $\begin{array}{l}\text { Sample } \\
\text { size for } \\
\text { teacher }\end{array}$ & $\begin{array}{l}\text { Percenta } \\
\text { ge } \%\end{array}$ \\
\hline Kandara & 55 & 0.132 & 7 & 17.5 & 726 & 0.107 & 78 & 19.50 \\
\hline Mathioya & 31 & 0.132 & 4 & 10 & 370 & 0.107 & 39 & 9.75 \\
\hline Kangema & 27 & 0.132 & 4 & 10 & 327 & 0.107 & 35 & 8.75 \\
\hline Kigumo & 37 & 0.132 & 5 & 12.5 & 392 & 0.107 & 42 & 10.50 \\
\hline Muranga East & 30 & 0.132 & 4 & 10 & 361 & 0.107 & 38 & 9.50 \\
\hline Muranga South & 40 & 0.132 & 5 & 12.5 & 556 & 0.107 & 59 & 14.75 \\
\hline Kahuro & 38 & 0.132 & 5 & 12.5 & 400 & 0.107 & 43 & 10.75 \\
\hline Gatanga & 46 & 0.132 & 6 & 15 & 620 & 0.107 & 66 & 16.50 \\
\hline Total & $\mathbf{3 0 4}$ & $\mathbf{0 . 1 3 2}$ & $\mathbf{4 0}$ & $\mathbf{1 0 0 . 0 0}$ & $\mathbf{3 , 7 5 2}$ & $\mathbf{0 . 1 0 7}$ & $\mathbf{4 0 0}$ & $\mathbf{1 0 0 . 0 0}$ \\
\hline
\end{tabular}

The table 1 indicates that out of 3752 teachers in 304 schools, 400 teachers and 40 schools were sampled from the 8 sub counties within the county of Murang'a.

\section{Results and Discussion}

\section{Response Rate}

Out of the four hundred (400) teachers who were sampled, two hundred and ninety-eight (298) responded to the questionnaires that were administered. This gave a response rate of $74.5 \%$ which according to Mugenda and Mugenda (2003) is satisfactory to conduct data analysis and interpretation of the findings. Similarly, Saunders, Lewis and Thornhill (2007) also recommended a response rate of above $50 \%$ for the purpose of conducting statistical analysis.

\section{Respondents Demographic Information}

The study assessed the demographic characteristics of the respondents for the purpose of providing general information about them. This section therefore presents the findings on each of the demographic characteristics of the respondents. The key characteristics of the respondents under consideration in this research were gender, age, years worked with TSC (tenure) and level of education. Table 2 shows the results.

Table 2: Demographic Characteristics of the Respondents

\begin{tabular}{llll}
\hline Characteristics & Category & Frequency & Percent \\
\hline Gender & Male & 161 & 54 \\
& Female & 137 & 46 \\
Total & $21-30$ Years & $\mathbf{2 9 8}$ & $\mathbf{1 0 0}$ \\
& $31-40$ Years & 75 & 25.2 \\
& $41-50$ Years & 96 & 32.2 \\
& Above 50 Years & 79 & 26.5 \\
Number of years you have worked with TSC & Total & 48 & 16.1 \\
(Tenure) & Less than 5 years & $\mathbf{1 0 0}$ \\
& 5-10 years & $\mathbf{2 9 8}$ & 29.5 \\
& $11-20$ years & 88 & 27.5 \\
Level of Education & More than 20 years & 82 & 17.1 \\
& Total & 51 & 25.8 \\
& Diploma level & 77 & 100
\end{tabular}


With reference to the respondents' gender, the results as evidenced in Table 2 show that male were the majority of the participants in the study as represented by $54 \%$, while $46 \%$ were females which points to low gender disparity among public secondary school teachers in Murang'a County who were the respondents. According to Zulfqar et al. (2011), men are more satisfied whenever they achieve more on the job whereas women tend to value both work and family which points to the fact that the male teachers who made up the majority are likely to put their job first hence unlikely to quit due to family matters. The results also imply that the selected sample for the study was gender representative.

In regard to age bracket the largest proportion of the sample as represented by $32.2 \%$ was aged between 31 to 40 years followed by $26.5 \%$ of the participants of the study who were aged between 41 to 50 years while a further $25.2 \%$ were aged between 21 to 30 years. Only $16.1 \%$ of the sample of the study was aged above 50 years. According to Malik (2011), an employees' age has an effect on their perception of satisfaction and commitment which consequently affects turnover intentions. In this regard, there is almost an equal distribution of age among respondents. Wren, Berkowitz and Grant (2014), posit that while employees who are aged above 50 years tend to show inclination to stay on in the organization, their younger counterparts have more opportunities and therefore tend to gauge the satisfaction derived from the current employment. The results provide an indication that a higher proportion of the study's participants, $57.4 \%$, were aged below 40 years while those above 40 years represented $42.3 \%$.

The results showed that the largest proportion of the sample, $29.5 \%$ had worked with TSC for a period of less than five years while a further $27.5 \%$ indicated that they had worked with TSC between 5 to 10 years. The results also showed that $17.1 \%$ of the participants of the study indicated that they had worked with TSC between 11 to 20 years while a further $25.8 \%$ indicated that they had worked with TSC for more than 20 years. The findings imply that most of the respondents involved in this study, $70.5 \%$, had worked with TSC for more than 5 years. Further, according to Michel, Kavanagh and Tracey (2013), long tenured employees exhibit higher levels of job embeddedness and therefore tend to show little proclivity to quit.

Majority of the respondents as represented by $68.1 \%$ had bachelor degree while a further $16.8 \%$ had post graduate level of education. Only $14.4 \%$ of the sampled teachers indicated that they had diploma level of education while a further $0.7 \%$ indicated other levels of education. The findings in this section provide an indication that based on the fact that majority of the respondents possess high level of academic qualification (bachelor degree and postgraduate level), the likelihood of turnover is high which according to Brown et al. (2010) as results of attaining higher academic qualifications, employees agitate for better remunerations and other benefits which might not be provided by the current employer.

\section{Turnover Intentions}

This was the dependent variable of the study and was considered a dichotomous variable. This section of the analysis therefore presents the results on turnover intentions. Respondents were asked whether they will leave the current job if they get a better job. The findings are presented in table 3.

Table 3: Turnover Intentions

\begin{tabular}{llc}
\hline $\begin{array}{l}\text { Will leave the current job } \\
\text { if I get a better job }\end{array}$ & Frequency & Percentage \\
\hline No & 51 & 17.1 \\
Yes & 247 & 82.9 \\
Total & $\mathbf{2 9 8}$ & $\mathbf{1 0 0}$ \\
\hline
\end{tabular}

As shown in table 3, 82.9\% (247) of the teachers had the intention to leave. However, $17.1 \%$ (51) of them intend to stay. The findings provide a clear indication that those teachers in public secondary schools in Murang'a County Kenya who were the respondents of the study that intend to leave are more than those that want to stay. There is therefore need to address high intention to leave by teachers to avoid compromising quality of education. Ngo-Henha, (2017) suggests that management effort to evaluate and meet the employees' expectations can be considered as a strategy to retain and ultimately control turnover intentions (intention to leave).

\section{Hypotheses Testing}

To further understand the relationship between turnover intentions and demographic variables (gender, age, tenure and education level) and whether there is significant relationship between the independent and dependent variables the variables were cross tabulated and Chi-square statistics determined. First, the hypothesis test to determine the relationship between gender and turnover intentions was done. 
The results are as shown in table 4.

Table 4: Cross Tabulation of Turnover Intentions and Gender

\begin{tabular}{|c|c|c|c|c|c|c|}
\hline \multicolumn{7}{|c|}{ Turnover intention* Respondent Gender Cross tabulation } \\
\hline & & & & Male & Female & Total \\
\hline \multirow{9}{*}{$\begin{array}{l}\text { Turnover } \\
\text { intention }\end{array}$} & \multirow[t]{3}{*}{ Yes } & \multicolumn{2}{|l|}{ Count } & 132 & 115 & 247 \\
\hline & & \multicolumn{2}{|c|}{ Expected Count } & 133.4 & 113.6 & 247 \\
\hline & & $\begin{array}{l}\% \text { within } \\
\text { gender }\end{array}$ & Respondent & $82.00 \%$ & $83.90 \%$ & $82.90 \%$ \\
\hline & \multirow[t]{3}{*}{ No } & \multicolumn{2}{|l|}{ Count } & 29 & 22 & 51 \\
\hline & & \multicolumn{2}{|c|}{ Expected Count } & 27.6 & 23.4 & 51 \\
\hline & & $\begin{array}{l}\% \text { within } \\
\text { gender }\end{array}$ & Respondent & $18.00 \%$ & $16.10 \%$ & $17.10 \%$ \\
\hline & \multirow[t]{3}{*}{ Total } & \multicolumn{2}{|l|}{ Count } & 161 & 137 & 298 \\
\hline & & \multicolumn{2}{|c|}{ Expected Count } & 161 & 137 & 298 \\
\hline & & $\begin{array}{l}\% \text { within } \\
\text { gender }\end{array}$ & Respondent & $100.0 \%$ & $100.0 \%$ & $100.00 \%$ \\
\hline \multicolumn{2}{|c|}{ Chi-Square Tests } & \multicolumn{2}{|r|}{ value } & \multicolumn{2}{|c|}{ df } & Asymp. Sig. (2-sided) \\
\hline \multicolumn{2}{|c|}{ Pearson Chi-Square } & \multicolumn{2}{|r|}{$0.199 \mathrm{a}$} & \multicolumn{2}{|c|}{3} & 0.655 \\
\hline \multicolumn{2}{|c|}{ Likelihood Ratio } & \multicolumn{2}{|r|}{.200} & \multicolumn{2}{|c|}{3} & 0.655 \\
\hline
\end{tabular}

The results presented in Table 4 show the cross tabulation and chi-square analysis between turnover intentions and gender of the respondents. The study sought to test whether there was significance relationship between turnover intentions and teachers' gender. The cross-tabulation results show association between gender and turnover intention. This is because in all cases there is a difference between observed and expected counts. However, the chi-square results show that turnover intentions and gender had an insignificant association since the significant values 0.655 was greater than 0.05 . The hypothesis was therefore not rejected. This implies that gender difference does not affect turnover intentions of the teachers. The results were in line with the outcome of the study by Hayes (2015) and Likoko et al. (2017) who also found insignificant effect of gender on turnover intentions. However, these results contradicted the findings of Begüm et al. (2015) which established a significant relationship between gender and turnover intentions.

Secondly the cross tabulation of age and turnover intention and its corresponding Chi-square statistics was done to test the second hypothesis. The results are presented in table 5.

Table 5: Cross Tabulation of Turnover Intentions and Age Bracket

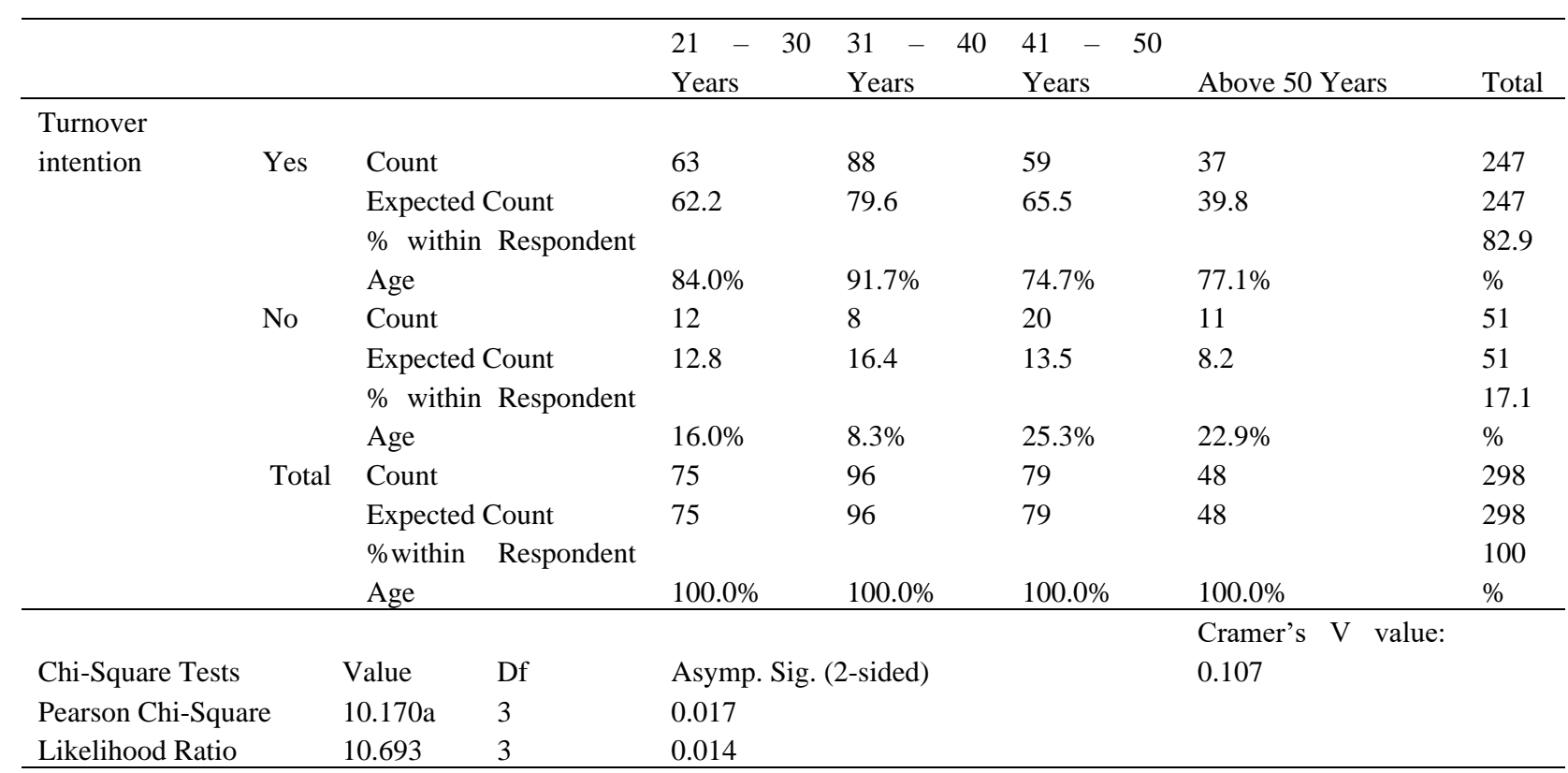

a. 0 cells $(0.0 \%)$ have expected count less than 5 . The minimum expected count is 8.21 . 
The results presented in Table 5 show the cross tabulation and Chi-square analysis between turnover intentions and age bracket of the respondents. The cross tabulation results show association between age and turnover intentions. The study sought to test whether there was significant relationship between turnover intentions and teachers' age bracket. The Chi-square results show that turnover intentions and age bracket had significant association $\chi^{2}=10.170 \mathrm{a}(\mathrm{p}=0.017)$. The hypothesis was therefore rejected. However, the Cramer's V Value of 0.107 indicates the association is not strong. This implies that there is a significant association between age bracket and turnover intentions of teachers in public secondary schools in Murang'a, Kenya though the association is not strong.

From table it can be observed that between age brackets $21-50,210(63 \%)$ respondents indicated intention to leave while within the same age bracket $40(77.1 \%)$ indicated intention to stay. This shows these age brackets play critical role in teachers' decision to intend to stay or leave their employment. These findings confirmed the findings by Hayes (2015), Begüm et al. (2015) and Likoko et al. (2017) which established significant relationship between age and turnover intentions. Based on Organization equilibrium theory, if an organization does not provide better terms for young people who are joining their firms the likelihood of them leaving would be high once they progress in their years if they feel their contribution is more than organization's inducements.

Thirdly, a cross tabulation and Chi-square analysis was done for tenure and turnover intentions and the results are shown in table 6

Table 6: Cross Tabulation of Turnover Intentions and Tenure

\begin{tabular}{|c|c|c|c|c|c|c|c|c|}
\hline & & & & $\begin{array}{l}\text { Less than } 5 \\
\text { years }\end{array}$ & $\begin{array}{l}5-10 \\
\text { years }\end{array}$ & $\begin{array}{l}11-\quad 20 \\
\text { years }\end{array}$ & $\begin{array}{l}\text { More than } 20 \\
\text { years }\end{array}$ & Total \\
\hline \multirow[t]{8}{*}{$\begin{array}{l}\text { Turnover } \\
\text { intention }\end{array}$} & \multirow[t]{3}{*}{ Yes } & \multicolumn{2}{|l|}{ Count } & 74 & 74 & 40 & 59 & 247 \\
\hline & & \multirow{2}{*}{\multicolumn{2}{|c|}{$\begin{array}{l}\text { Expected Count } \\
\% \text { within Number of years you have } \\
\text { worked with TSC }\end{array}$}} & 72.9 & 68 & 42.3 & 63.8 & $\begin{array}{l}247 \\
82.9\end{array}$ \\
\hline & & & & $84.10 \%$ & $90.2 \%$ & $78.40 \%$ & $76.60 \%$ & $0 \%$ \\
\hline & \multirow[t]{3}{*}{ No } & \multicolumn{2}{|l|}{ Count } & 14 & 8 & 11 & 18 & 51 \\
\hline & & \multirow{2}{*}{\multicolumn{2}{|c|}{$\begin{array}{l}\text { Expected Count } \\
\% \text { within Number of years you have } \\
\text { worked with TSC }\end{array}$}} & 15.1 & 14 & 8.7 & 13.2 & 51 \\
\hline & & & & $15.90 \%$ & $9.80 \%$ & $21.60 \%$ & $23.40 \%$ & $\begin{array}{l}17.1 \\
0 \%\end{array}$ \\
\hline & \multirow[t]{2}{*}{ Total } & \multicolumn{2}{|l|}{ Count } & 88 & 82 & 51 & 77 & 298 \\
\hline & & \multicolumn{2}{|c|}{$\begin{array}{l}\text { Expected Count } \\
\% \text { within Number of years you have } \\
\text { worked with TSC }\end{array}$} & $100 . \%$ & $100 . \%$ & $100 . \%$ & $100 . \%$ & $\begin{array}{l}298 \\
100 . \\
\% \\
\end{array}$ \\
\hline Chi-Squar & & Value & $\mathrm{df}$ & \multicolumn{5}{|c|}{ Asymp. Sig. (2-sided) } \\
\hline \multicolumn{2}{|c|}{ Pearson Chi-Square } & $6.062 \mathrm{a}$ & 3 & \multicolumn{5}{|c|}{0.109} \\
\hline \multicolumn{2}{|c|}{ Likelihood Ratio } & 6.313 & 3 & 0.097 & & & & \\
\hline
\end{tabular}

The results presented in Table 6 show the cross tabulation and chi-square analysis between turnover intentions and tenure of the respondents. The cross-tabulation results indicate a relationship exist between tenure and turnover intentions. The study sought to test whether there was significant relationship between turnover intentions and teachers' tenure. However, the Chi-square results show that turnover intentions and tenure had insignificant association $\chi^{2}=6.062 \mathrm{a}(\mathrm{p}=0.109)$.

The hypothesis was therefore not rejected. This implies that tenure difference did not affect turnover intentions of the teachers.

The results were consistent with the findings of Hayes, (2015) which established an insignificant relationship between tenure and turnover intentions. However, these findings contradicted the findings by Likoko et al. (2017) among academic staff in diploma teacher's college in Kenya which indicated significant effect of tenure on turnover intentions.

To find the relationship between education level and turnover intention the two variables were cross tabulated and Chi square statistics determined. The results are shown in table 7. 
Table 7: Cross Tabulation of Turnover Intentions and Education Level

\begin{tabular}{|c|c|c|c|c|c|c|c|}
\hline & & $\begin{array}{l}\text { Respondent } \\
\text { Level of } \\
\text { Education }\end{array}$ & $\begin{array}{l}\text { Diploma } \\
\text { level }\end{array}$ & $\begin{array}{l}\text { Bachelor } \\
\text { degree level }\end{array}$ & $\begin{array}{l}\text { Post } \\
\text { Graduate } \\
\text { level }\end{array}$ & Any other & Total \\
\hline \multirow{16}{*}{$\begin{array}{l}\text { Turnover } \\
\text { intention }\end{array}$} & Yes & Count & 33 & 167 & 46 & 1 & 247 \\
\hline & & Expected Count & 35.6 & 168.3 & 41.4 & 1.7 & 247 \\
\hline & & $\% \quad$ within & $13.40 \%$ & $67.60 \%$ & $18.60 \%$ & $0.40 \%$ & \\
\hline & & $\begin{array}{l}\text { Turnover } \\
\text { intention }\end{array}$ & & & & & $100.00 \%$ \\
\hline & No & Count & 10 & 36 & 4 & 1 & 51 \\
\hline & & Expected Count & 7.4 & 34.7 & 8.6 & 0.3 & 51 \\
\hline & & $\% \quad$ within & $19.60 \%$ & $70.60 \%$ & $7.80 \%$ & $2.00 \%$ & $100.00 \%$ \\
\hline & & $\begin{array}{l}\text { Turnover } \\
\text { intention }\end{array}$ & & & & & \\
\hline & Total & Count & 43 & 203 & 50 & 2 & 298 \\
\hline & & Expected Count & 43 & 203 & 50 & 2 & 298 \\
\hline & & $\% \quad$ within & $100.0 \%$ & $100.00 \%$ & $100.0 \%$ & $100.0 \%$ & $100.00 \%$ \\
\hline & & $\begin{array}{l}\text { Turnover } \\
\text { intention }\end{array}$ & & & & & \\
\hline & & Value & $\mathrm{df}$ & $\begin{array}{l}\text { Asymp. Sig. } \\
\text { (2-sided) }\end{array}$ & & & \\
\hline & $\begin{array}{l}\text { Pearson } \\
\text { Chi-Square }\end{array}$ & $5.651 \mathrm{a}$ & 3 & 0.13 & & & \\
\hline & $\begin{array}{l}\text { Likelihood } \\
\text { Ratio }\end{array}$ & 5.754 & 3 & 0.124 & & & \\
\hline & $\begin{array}{l}\text { Linear-by- } \\
\text { Linear } \\
\text { Association }\end{array}$ & 2.417 & 1 & 0.12 & & & \\
\hline
\end{tabular}

The results for cross tabulation in Table 7 show existence of relationship between education level and turnover intentions. However, the Chi-square results indicate insignificant association between education level and turnover intentions $\left(\chi^{2}=5.651, p=0.13\right)$. The hypothesis was therefore not rejected. This means that among teachers in public secondary schools in Murang'a County Kenya, educational level is insignificant predictor of turnover intentions. These study findings contradicted the findings by Agyeman and Ponniah (2014) and Likoko et al. (2017), which found a positive and significant association between higher qualifications and turnover intentions.

\section{Conclusions}

Demographic factors have been documented to have an association with employees' turnover intentions. However this association among public secondary schools had not been given attention. This study was thus out to establish this association among public secondary schools' teachers in Murang'a County, Kenya. The findings revealed that age had significant association with turnover intentions of public secondary schools' teachers in Murang'a. However, gender, tenure and educational level were found not to have significant association with turnover intentions of teachers in public secondary schools in Murang'a County.

Based on the findings of this study it was concluded that age plays a significant role in turnover intentions decisions of teachers in public secondary schools in Kenya. There is therefore need to address the needs of different age brackets in order to increase intention to stay among teachers.

On the basis of this finding it is therefore recommended that teachers' employer should prepare teachers on what to expect as far as their job requirements and career progression is concerned as they progress in age. This will help individuals to have a clear understanding on what they can achieve in their profession at different stages of their lives (age bracket) and thus help them plan and be focused in realizing their aspiration within the profession.

Since different studies have given varying results this study therefore provides additional evidence to HRM literature that the effect of demographic factors on turnover intentions depends on the context in which variables interact. The study also provides evidence 
that cross tabulation and Chi-square analysis a method that is mostly used in marketing research can also be used in other areas of research.

This study was not without limitation and therefore future research can focus to address these limitations. First, this study only focused on four demographic factors, thus future study should explore the association of other demographic factors on turnover intentions among teachers in public secondary schools. The study also was only interested with whether there was significant association between the demographic factors and turnover intentions and the strength of association but did not interrogate the direction of the relationship. Future research should establish the strength and the direction of the relationship using different analysis method and also consider their moderating effect on turnover intentions.

Since this study was in the education sector, studies in other sector both public and private can shed light on the association between these variables. The schools and teachers sampled were from Murang'a County only which could have been different in physical, economic and demographic characteristics with other regions in Kenya. This would make the findings not generalizable to other regions in Kenya and therefore future research should include other regions.

\section{References}

Agyeman, C. M., \& Ponniah. V.M. (2014). Employee demographic characteristics and their effects on turnover and retention in Msmes. International Journal of Recent Advances in Organizational Behaviour and Decision Sciences, 1 (1), 12-29

Ajayi, S., \& Olatunji O. (2017). Demographic analysis of turnover intentions amongst Nigerian high school teachers. Australian and International Journal of Rural Education, 27(1), 62-87

Bal, P. M., De Cooman, R., \& Mol, S. T. (2013). Dynamics of psychological contracts with work engagement and turnover intention: The influence of organizational tenure. European Journal of Work and Organizational Psychology, 22, 107-122. doi:10.1080/1359432X.2011.626198

Banken H.H.M. (2010). Do HR practices reduce turnover intentions and is this relation mediated by employee engagement. (Unpublished master's thesis). Tilburg University.

Begüm D. E., Orhan A., \& Haluk T. (2015). The relationship between turnover intention and demographic factors in hotel businesses: A study at five-star hotels in Istanbul, Turkey. Procedia - Social and Behavioral Sciences, 207, 385 - 397.

Bhat, Z. F. (2014). HR practices and employee turnover intentions. A correlational analysis. Global Journal for Research Analysis International, 3 (7), 171-173.

Bornstein, M., Jager, J., \& Putnick, D. (2013). Sampling in developmental science: Situations, shortcomings, solutions, and standard. Developmental Review, 33, 357-370.doi:10.1016/j.dr.2013.08.003

Brown, M., Hyatt, D., \& Benson, J. (2010). Consequences of performance appraisal experience. Personnel Review, 39(3), $375-396$.

Butler, S. S., Brennan-Ing, M., Wardamasky, S., \& Ashley, A. (2014). Determinants of longer job tenure among home care aides: What makes some stay on the job while others leave? Journal of Applied Gerontology, 33, 164-188.doi: $10.1177 / 0733464813495958$

Chughtai, T.A. (2013). Role of HR practices in turnover intentions with the mediating effect of employee engagement. Wseas Transactions on Business and Economics, (2), 10, 97-103.

Cotton, J. L., \& Tuttle, J. M. (1986). Employee turnover: A meta-analysis and review with implications for research. The Academy of Management Review, 11(1), 55-70.

Couch, K. A. (2011). Tenure, turnover, and earnings profiles in Germany and the United States. Journal of Business \& Economics Research, 1(9), 1-9. Retrieved from http://www.berjournal.com

Crospranzano, R., \& Mitchell, M. S. (2005). Social exchange theory: An interdisciplinary review. Journal of Management, 31,874 -900 .

Eisenberger, R., Huntington, R., Hutchinson, S., \& Sowa, D. (1986). Perceived organizational support. Journal of Applied Psychology, 71, (3), 500-507.

Feick, L. F. (1984) Analyzing marketing research data with association models. Journal of Marketing Research, 21, 376-378

Field, A. P. (2009). Discovering statistics using SPSS, 2nd edition. London: Sage.

Firebaugh, G. (2008). Use panel data to study individual change and repeated cross-section data to study social change: In the seven rules for Social Research (Chapter 6). Princeton, NJ: Princeton University Press.

Fishbein, M., \& Ajzen, I. (1975). Belief, attitude, Intention and behavior: An introduction to theory and research, Addison-Wesley, Boston, MA.,

Gay, L., Mills, G., \& Airasian, P. (2006). Educational research: Competencies for analysis and applications. New Jersey: Pearson Education.

Hayes, T.M (2015). Demographic characteristics predicting employee turnover intentions. Doctoraldissertation.Retrievedfrom:https://scholarworks.waldenu.edu/cgi/viewcontent.cgi?article=2537zcontext $=$ dissertations.

Kamau, O. M., Muathe, S. M. A., \& Wainaina, L. (2020a). HRM practices employee engagement and teachers turnover intentions: A cross-sectional study from public secondary schools in Kenya. International Journal of Academic Research in Business and Social Sciences, 10(9), 257-271. 
Kamau, O. M., Muathe, S. M. A., \& Wainaina, L. (2020b). A logit test of turnover intentions of teachers professionals. The role of HRM practices and community embeddedness in public secondary schools in Murang'a County, Kenya. European Scientific Journal, 16(25), 108-123.

Kothari, C. R. (2004). Methods and techniques: Research methodology, (2nd ed.). New Delhi: New Age International Publishers Ltd.

Krishman, S.K., \& Singh, M. (2010). Outcomes of intentions to quit of Judean Professionals. Human Resource Management, 49(3):28-36.

Likoko, S. Ndiku J., \& Mutsotso, S. (2018). Influence of demographic characteristics on turnover intentions among the academic staff in public diploma teacher training colleges in Kenya. International Journal of Science and Research (IJSR). 27(1), 62-87. DOI: 10.21275/ART2019465

Maden, C. (2014). Impact of fit, involvement, and tenure on job satisfaction and turnover intention. The Service Industries Journal, 34, 1113-1133. doi:10.1080/02642069.2014.939644

Malik, M. (2011). Role Overload, turnover and their effect on layoff survivor's job retention and productivity. Interdisciplinary Journal of contemporary Research in Business, 2(11), 427-440.

Manthi A.K., Kilika. J.M., \& Kimencu, L. (2018). How do human resource management practices predict employee Turnover Intentions: An empirical survey of teacher straining colleges in Kenya. International Journal of Business Administration. 9(4). 201-213.

March J. G. \& Simon H. A. (1958). Organizations, Wiley, New York.

Martin, A., Roodt, G. (2008). Perceptions of organizational commitment, job satisfaction and turnover intentions in a post-merger South African. Journal of Industrial Psychology, 34 (1): 23-31.

Mensah R. D. (2014). Effects of human resource management practices on retention of employees in the banking industry in Accra, Ghana. (Unpublished PhD Thesis) Kenyatta University.

Mitchel, J.W., Kavanagh, M.J., \& Tracey, J.B. (2013). Got support? The impact of supportive work practices on the perceptions, motivation, and behavior of customer contact employees. Cornell Hospitality Quarterly, 54(2), 161-173.

Monks, J. (2012). Job turnover among university presidents in the United States of America. Journal of Higher Education Policy \& Management, 34, 139-152. doi:10.1080/1360080X.2012.662739

Mugenda, O. M., \& Mugenda, A. (2003). Research methods: Qualitative and quantitative approaches. Nairobi: ACTS Press.

Mutune, K. J. M., \& Orodho, J. A. (2014). Teachers' turnover: What are the explanatory variables in public secondary schools in Mbeere south sub-county, Embu County, Kenya? IOSR Journal of Humanities and Social Science (IOSR-JHSS) 19 (12), 11-24 Retrieved from www.iosrjournals.org

$\mathrm{Ng}$, T. W. H., \& Sorensen, K. L. (2008). Toward a further understanding of the relationships between perceptions of support and work attitudes: A meta-analysis. Group \& Organization Management, Vol. 33, No. 3, pp. 243-268.

Ngo-Henha, P.E. (2017). A review of turnover intentions theories. International Journal of Economics and Management Engineering, 11(11), 2760-2767.

Nhema, N., \& Mutenheri, E. (2016). Factors that Influence the turnover intentions of employees in the tourism sector in Zimbabwe. International Journal of Management Sciences and Business Research, 5(12), 158-165.

Park, J. \& Kim, T. (2009). Do types of organizational culture matter in nurse job satisfaction and turnover intention? Leadership and Health Sciences, 22, (1) 20-28

Rhoades, L., \& Eisenberger, R. (2002). Perceived organization support: a review of literature. Journal of Applied Psychology, 87, 698-714.

Stanley, L., Vandenberghe, C., Vandenberg, R., \& Bentein, K. (2013). Commitment profiles and employee turnover. Journal of Vocational Behavior, 82, 176-187. doi:10.1016/j.jvb.2013.01.011

Saunders, M., Lewis, P., \& Thornhill, A. (2009). Research methods for business students, $5^{\text {th }}$ edition, Great Britain, Prentice Hall.

Steel, R.P., \& Ovalle, N.K. (1984). A review and meta-analysis of research on the relationship between behavioural intentions and employee turnover. Journal of Applied Psychology, 69(4), 673-686. https://doi.org/10.1037/0021-9010.69.4.673

Tarmizi, A.N. (2008). Quality work life and turnover intentions: The mediating effect of career and organizational commitment, (Masters Thesis). Business Administration, USM. Retrieved on 30/10/2017, URL: http://eprints,um.my/id/eprint/25416

Verhees, J.M.A. (2012). The relationship between training and employees' turnover intentions and role of organizational commitment. (Unpublished masters thesis), Tilburg university, Netherlands.

Wamukuru, D. K. (2016). Modelling the effects of teacher demand factors on teacher understaffing in public secondary schools in Kenya. Journal of Education and Practice www.iiste.org. 7, (3). 147-153.

Wittmer, J. L., Martin, J. E., \& Tekleab, A. G. (2010). Procedural justice and work outcomes in a unionized setting: the mediating role in leader member exchange. American Journal of Business, 25(2), 55-70.

Wren, B., Berkowitz, D., \& Grant, E. (2014). Attitudinal, personal and job related predictors of sales persons' turnover. Marketing Intelligence \& Planning, 32, 107-123. Doi: 10.1108/MIP-04-2013-0061

Wright, P. M., Coff, R., \& Moliterno, T. P. (2014). Strategic human capital: Crossing the great divide. Journal of Management, 40, 353-370. doi: 10.1177/0149206313518437

Yamane T. (1967). Statistics: An introduction analysis ( $2^{\text {nd }}$ ed.), New York: Harper and Row 
Zulfqar, A. B., Sharif, B., Saeed, A., \& Niazi, M. K. (2011). Impact of human resource practices on employee perceived performance in banking sector of Pakistan. African Journal of Business Management, 6(1), 323-332.

Publisher's Note: SSBFNET stays neutral with regard to jurisdictional claims in published maps and institutional affiliations.

\section{(c) (1)}

(C) 2021 by the authors. Licensee SSBFNET, Istanbul, Turkey. This article is an open access article distributed under the terms and conditions of the Creative Commons Attribution (CC BY) license (http://creativecommons.org/licenses/by/4.0/).

International Journal of Research in Business and Social Science (2147-4478) by SSBFNET is licensed under a Creative Commons Attribution 4.0 International License. 